NBER WORKING PAPER SERIES

\title{
STRESSED OUT ON FOUR CONTINENTS: TIME CRUNCH OR YUPPIE KVETCH?
}

\author{
Daniel S. Hamermesh \\ Jungmin Lee \\ Working Paper 10186 \\ http://www.nber.org/papers/w10186
}

\author{
NATIONAL BUREAU OF ECONOMIC RESEARCH \\ 1050 Massachusetts Avenue \\ Cambridge, MA 02138 \\ December 2003
}

Edward Everett Hale Centennial professor of economics, University of Texas at Austin, research associate, National Bureau of Economic Research, and program director, Forschungsinstitut zur Zukunft der Arbeit (IZA); Ph.D. candidate, University of Texas at Austin. We thank Lisa Dickson, Abe Dunn, Yuqian Lu and Mark Pocock for helpful assistance, and Jennifer Hunt, Gerald Oettinger, Stephen Trejo and participants in seminars at a number of universities for very useful comments. The Australian Department of Family and Community Services and Mark Wooden of the Melbourne Institute for Applied Economic and Social Research kindly made the first wave of the HILDA available expeditiously. Jürgen Schupp of the Deutsches Institut für Wirtschaftsforschung graciously gave us the 2002 German data on an accelerated basis, and Gert Wagner added the question to that data set. Thomas Crossley provided access to the Canadian GSS data during Hamermesh's tenure as the Hooker Professor at McMaster University. The Alfred P. Sloan Foundation supported the research underlying this study. None of these organizations is responsible for any of the findings. ("Kvetch" is defined in the Merriam-Webster Dictionary as "habitual complaint.") The views expressed herein are those of the authors and not necessarily those of the National Bureau of Economic Research.

(C)2003 by Daniel S. Hamermesh and Jungmin Lee. All rights reserved. Short sections of text, not to exceed two paragraphs, may be quoted without explicit permission provided that full credit, including $(\mathrm{C}$ notice, is given to the source. 
Stressed Out on Four Continents: Time Crunch or Yuppie Kvetch?

Daniel S. Hamermesh and Jungmin Lee

NBER Working Paper No. 10186

December 2003

JEL No. J220, J160

\section{ABSTRACT}

Social commentators have pointed to problems of women workers who face "time stress" - an absence of sufficient time to accomplish all their tasks. An economic theory views time stress as reflecting how tightly the time constraint binds households. Time stress will be more prevalent in households with higher incomes and whose members work longer in the market or on "required" homework. Evidence from Australia, Canada, Germany, Korea and the United States corroborates this view. Adults in higher-income households perceive more time stress for the same amount of time spent in market work and household work. The importance of higher full incomes in generating time stress is not small, particularly in North America - much is "yuppie kvetch." While time stress is most prevalent among working wives, a decomposition suggests that women would perceive more time stress than men even if both worked the same number of hours in the market and at home.

Daniel S. Hamermesh

Department of Economics

University of Texas

Austin, TX 78712

and NBER

hamermes@eco.utexas.edu

Jungmin Lee

Department of Economics

University of Texas

Austin, TX 78712

junglee@eco.utexas.edu 


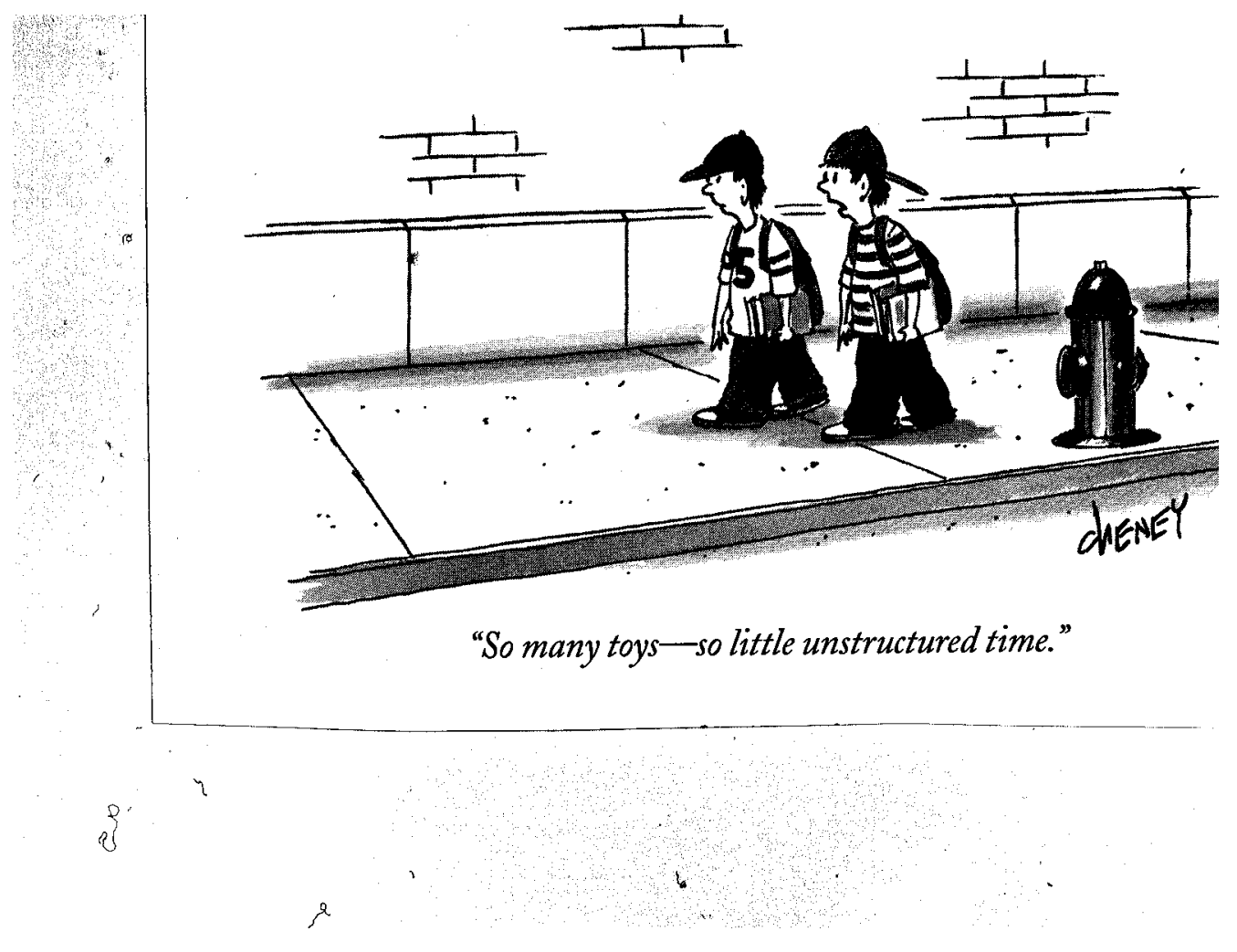




\section{Introduction}

Substantial attention has been paid in the popular media and among social commentators (e.g., Hochschild, 1997) to the issue of a "time crunch."-a "shortage" of time faced by today's worker/consumers. ${ }^{1}$ This issue generates much concern about the problems of working people, and working couples in particular, who have two market jobs and may be unable or unwilling to substitute purchased services for time spent maintaining a household. It is tied to surprise at the possible failure of annual market work hours to decline (Schor, 1991) and at the increasing fraction of adults who participate in the labor market (so that market work per adult in the United States has probably risen since 1950). The essence of the problem was captured by a young working mother of three pre-school children, "With the kids and the house, I often feel I have four hours of tasks and only two hours to do them in.",2

Economists have not studied this problem at all, other than to observe changing patterns of time use. There has, however, been some research by social psychologists and sociologists on the subject. Much simply uses time-budget surveys to identify demographic correlates of total time spent in market and household production, equating stress (a subjective outcome) with time use (an objective outcome). A few studies (Lochhead, 2002, and Holz, 2002) have used small representative surveys (for Canada and Germany respectively) to relate subjective feelings of time stress to demographic characteristics and to hours of market work.

Time stress is a problem analogous to poverty: Both reflect the scarcity of resources, time in the former case, goods in the latter. The only difference is that in a growing economy the goods constraint will relax over time, while the time constraint cannot. The time crunch will become relatively more binding for more people. Once one thinks about time stress in this

\footnotetext{
${ }^{1}$ Newspaper stories discussed the issue, e.g., http://www.pressdemo.com/outlook98/stories/39353.html, and are legion today. Government publications such as http://www.ed.gov/pubs/PFIE/constrat.html became noticeable during the 1990s, although Linder (1970) pointed it out a generation earlier. That there may be a link to economic variables is suggested by recent publicity for Alain Ducasse's gourmet lunch boxes, "The big question in our lives is how to be at the same time a hedonist and in a hurry." (The Economist, August 2, 2003, p. 49)

${ }^{2}$ Personal communication from Hannah E. Hamermesh, July 5, 2002.
} 
economic way, the approach to its study is immediately apparent: Greater time stress should result from an increasing relative abundance of goods, since time and purchased goods are not perfectly substitutable. It is not only the leisure class that will be "harried" (Linder, 1970): Any group, regardless of its hours of work, will perceive itself under increasing time stress as its ability to purchase market goods increases.

There are two central issues here for economists: 1) Do economists have anything useful to add to the discussion (other than more complex statistical techniques) beyond what scholars in other disciplines have offered? 2) If so, what is our comparative advantage? The former issue is crucial: While economists are increasingly engaged in empirical studies of subjective outcomes, in many cases our research addresses questions that scholars in other disciplines have already addressed, is not linked to economic theory, and/or uses different data sets but employs methods and approaches used many times before by others. ${ }^{3}$ On the second question, as in most cases in which economists have successfully addressed areas that had previously been considered outside our purview (e.g., Becker, 1976), our comparative advantage surely lies in adducing a maximizing theory to describe and predict behavior.

In Section II we thus derive an economic theory of time stress and generate predictions from it. The essential novelty is to link time stress to the shadow price of time, which allows us to treat it in the context of a model of the representative consumer who purchases goods and allocates time. Because the outcome is subjective, it is even more important than usual to test the theory on several data sets and allow for the possibility that the framing of the survey questions might incorrectly be seen as supporting or refuting the theory. Section III thus discusses a variety of data sets that are used in the subsequent analyses, which are presented in Section IV for each of Australia and Germany, Korea and Canada, and the United States. Section V explores the titular question of this study.

\footnotetext{
${ }^{3}$ A careful exception is DiTella et al (2001). Frey and Stutzer (2002) discuss a variety of determinants of subjective well-being, while Diener and Biswas-Diener (2002) survey the long-standing socialpscyhological literature.
} 


\section{An Economic Theory of Time Stress}

"Stress" has a large number of dictionary definitions; but the most relevant here is "physical, mental or emotional strain or tension." Time stress should thus be interpreted as strain or tension that is generated by feelings that the available time is insufficient to accomplish the desired activities. Time, like goods, is always insufficient—because time is limited, everyone is to some extent stressed.

While some of the predictions derived here could be generated if we define the household as maximizing some utility function defined over leisure and goods consumption, the particular role of a time constraint is clarified if we follow Becker (1965), introduce time explicitly into the model, and view households as producing commodities by combining home time, $\mathrm{T}-\mathrm{H}$, and goods $\mathrm{X}$. Commodities $\mathrm{Z}_{\mathrm{i}}$ are produced according to the household production functions:

(1) $\quad Z_{i}=Z_{\mathrm{i}}\left(\mathrm{T}_{\mathrm{i}}, \mathrm{X}_{\mathrm{i}}\right), \mathrm{i}=1,2$.

We assume that the household's utility function is:

$$
U\left(Z_{1}, Z_{2}\right)+V\left(H_{m}, H_{f}\right)
$$

where the subscripts $m$ and $f$ denote the husband and wife, and the $\mathrm{H}_{\mathrm{i}}$ denote market work. The function reflects the disutility of market work, with $\mathrm{U}$ and $\mathrm{V}$ assumed additively separable for simplicity. As usual, we assume that $\mathrm{V}_{\mathrm{j}}<0$ and $\mathrm{V}_{\mathrm{jj}}<0, \mathrm{U}_{\mathrm{i}}>0$ and $\mathrm{U}_{\mathrm{ii}}<0$. Perhaps most important, for now we do not examine the internal distribution of consumption within the household, implicitly thus assuming a unitary model of household decision-making.

As is usual in the time-goods model, let household production functions be characterized by fixed coefficients:

$$
T_{i}=t_{i} Z_{i} \text { and } X_{i}=b_{i} Z_{i}, i=1,2 \text {, }
$$

and let goods prices be $\mathrm{p}_{\mathrm{i}}$. The household's income, which is entirely spent on the $\mathrm{X}_{\mathrm{i}}$, is:

$$
\Sigma p_{i} X_{i}=H_{m} w_{m}+H_{f} w_{f}+I,
$$

where I is unearned income, and the $\mathrm{w}_{\mathrm{j}}$ are the spouses' wage rates. The household faces this goods constraint and the total time constraint: 
$\Sigma T_{i}=T-H_{m^{-}} H_{f}$.

The household's problem is then to maximize:

(5) $U()+.V()+.\mu\left(w_{m} H_{m}+w_{f} H_{f}+I-p_{1} b_{1} Z_{1}-p_{2} b_{2} Z_{2}\right)+\lambda\left(T-H_{m}-H_{f}-t_{1} Z_{1}-t_{2} Z_{2}\right)$

where $\mu$ is the Lagrangean multiplier on the goods constraint, and $\lambda$ is the Lagrangean multiplier on the time constraint. It seems reasonable to assume that time stress, a subjective measure, is positively related to the shadow price of time, $\lambda$. In order to simplify matters we assume that the husband's hours of market work are fixed, consistent with the widely observed near-zero elasticity of labor supply of married men.

One can show that $\partial \lambda / \partial I>0$ if:

(6) $w_{f} U_{11} U_{22}<V_{22}\left[p_{2} b_{2} t_{2} U_{11}+p_{1} b_{1} t_{1} U_{22}\right]$.

The left-hand side of (6) is proportional to the change in the marginal utility of an hour of market work by the wife in response to a unit change in the household's unearned income; the right-hand side stands in the same proportion to the change in the marginal utility of an hour of her time at home in response to the same change in unearned income. So long as the value of home time increases more in response to an increase in unearned income than does the value of time in the market, the shadow price of time rises with unearned income. Consider $\frac{\partial \lambda}{\partial w_{m}}$ and $\frac{\partial \lambda}{\partial w_{f}}$, the comparative-static effects of changes in wage rates. From the first-order condition, we have:

(7a) $\frac{\partial \lambda}{\partial w_{m}}=H_{m} \frac{\partial \lambda}{\partial I}$

and

(7b) $\frac{\partial \lambda}{\partial w_{f}}=\mu+H_{f} \frac{\partial \lambda}{\partial I}$.

Both of these are positive if (6) is satisfied. Finally, it is trivial to show that $\partial \lambda / \partial T<0$ always.

The results suggest that, if husband's hours of work are held constant, anything that raises the household's income - higher wage rates for either spouse, or additional unearned income- 
will increase the degree to which the time constraint binds. Obviously hours in the day are fixed, so that the economic meaning of the prediction $\partial \lambda / \partial T<0$ cannot be about a pure increase in available time. Rather, anything that makes the household more efficient in its home activities can be viewed as equivalent to an increase in effective time and should thus reduce the extent to which the time constraint binds.

Relaxing the assumption of fixed hours of work by the husband makes the predictions generally ambiguous. If, as seems consistent with evidence on labor supply elasticities, $\partial \mathrm{H}_{\mathrm{m}} / \partial \mathrm{w}_{\mathrm{m}} \geq 0$, the positive impact of higher husbands' wage rates on $\lambda$ becomes even larger when his work hours are allowed to vary. Obversely, the evidence on income effects suggests that $\partial \mathrm{H}_{\mathrm{m}} / \partial \mathrm{I} \leq 0$, so that the ceteris paribus positive impact of increases in unearned income on $\lambda$ is attenuated by the changes in husbands' work hours that they may induce.

We have implicitly treated the household as being characterized by a unitary model of household decision-making - we have assumed that there is a family utility function. A massive literature (summarized, e.g., by Lundberg and Pollak, 1996) suggests that families are more complex than this. So long as we assume that the household's maximization is a two-step process - determine hours of market work and the amount of the commodities to be produced independent of the sharing rule - the basic predictions of the model do not change when we assume a more complex decision-making process within the household.

This economic model describes the effects of several variables on the extent to which the time constraint binds the household. It presents a theory of the determination of the Lagrangean multiplier on the time constraint, $\lambda{ }^{4}$ For a given allocation of time to "work" activities, the predictions about the impacts on $\lambda$ of the $\mathrm{w}_{\mathrm{j}}, \mathrm{I}$ and $\mathrm{T}$ can be carried over, mutatis mutandis, into predictions about their effects on perceived time stress. Anything that reduces the time available for the production of household commodities, such as additional market work, will also increase

\footnotetext{
${ }^{4}$ Theorizing about the determinants of a Lagrangean multiplier is unusual, but see Weinberg (2001).
} 
time stress. We are thus equating subjective time stress with the unmeasurable, but predictable tightness of the time constraint that the household faces.

We wrote the production functions $\mathrm{Z}$ as identical across households, which much research has shown to be incorrect. Perhaps the major problem is the implicit assumption that people are equally efficient in combining goods and time regardless of their other characteristics. An important determinant of the productivity of time in the household is its members' health (Grossman, 1972). Better health makes one more efficient in producing commodities in the household, effectively raising the productivity of time and thus reducing time stress (and financial stress as well). Thus for theoretical reasons, and because health is likely to be correlated with the central variables on which we focus, full incomes and hours of work, it is crucial to account for differences in health in describing time stress.

\section{Data Sets for Studying Time Stress}

No large recent nationally random sample of Americans contains information on perceptions of time stress. Thus the predictions of Section II cannot be tested thoroughly on current or recent U.S. data. To compensate for this (ethnocentric) difficulty we use large data sets from several different countries (and a small data set from the U.S.). Because the samples of single individuals are not very large, and because the popular discussion of time stress revolves around the behavior of married couples, we restrict the analysis to male-female partnerships.

The Household, Income and Labour Dynamics in Australia (HILDA) survey contains information on perceived time stress and standard household demographic/economic variables (Wooden et al, 2002). Modeled after the U.S. Panel Study of Income Dynamics, the first wave, from 2001, obtained responses from 13,969 members of 7682 households. It addressed to each adult respondent a questionnaire including, "How often do you feel rushed or pressed for time? Almost always; often; sometimes; rarely; never."

The German Socio-economic Panel (SOEP) has 19 years of data, with the current sample containing approximately 12,000 households. (Wagner et al, 1993) Its sponsors included in the 
2002 wave a version of the same question on time stress that was contained in the HILDA. The question and possible responses are: "Think about the last four weeks. How often during this period did it happen that you felt rushed or under time pressure? Always; often; sometimes; almost never; never."

Neither of these data sets reports actual time spent in market work and on household tasks. In both respondents state how many hours per day or per week they usually spend in these activities. Thus like any retrospective data that are unconstrained by the need to sum to a fixed available time, they are subject to potential reporting problems. Fortunately the 1999 Korean Time Use Study (KTUS) includes the question: "How often do you feel rushed or pressed for time? Always; often; rarely; never." The survey covered 17,000 households, including all adult members. It obtained time diaries for each person for two days, as well as some demographic data. Unfortunately it lacks information on wages and incomes, which we must impute using a large contemporaneous Korean data set covering individuals.

In 1998 the Canadian General Social Survey included a time-diary component, so that like the KTUS the CGSS provides both actual and recall information on time use. Moreover, information is available on each respondent's income and that of her/his spouse. The drawback is that it included only one adult in each household, so that we cannot examine the time stress of spouses jointly. Also, the question on time stress was somewhat different from that in the other surveys: "How often do you feel rushed? Would you say it is every day; a few times a week; about once a week; about once a month; less than once a month; never."

Two small national U.S. surveys in the 1970s, the Quality of American Life Surveys (QAL) of 1971 and 1978 (Campbell, Converse and Rodgers, 1975; Campbell and Converse, 1984) included questions on time stress as part of their small samples of individuals. The question was: "In general, how do you feel about your time-would you say you always feel rushed even to do the things you have to do, only sometimes feel rushed, or almost never feel rushed?" The QAL contains no information on the time use of respondents' spouses other than an 
indicator of whether or not the spouse works; and there is no information on the respondents' allocation of non-market time. The analysis for the United States is thus based on individuals on whose spouses and on whom there is relatively little information. ${ }^{5}$

\section{The Determinants of Time Stress}

Our purpose is to link the data on perceived time stress to measures of time use, the scarcity of time for household production and the income used to purchase goods to combine with that time. We group Australia and Germany together because of the similarity of the questions about time stress and the underlying data on time use, and we group Korea and Canada together for the latter reason. In each Part we examine the distribution of perceived time stress and how it differs by sex. Each then proceeds to analyze the determinants of interpersonal differences in time stress. We restrict the analyses to couples in which at least one of the partners is working in the labor market. We also analyze married couples with both spouses working in the labor market - the archetypal couple in the social-psychological "time crunch" literature. Since the theory in Section II ignored corner solutions to the household's maximization problem, these latter results are especially worth attention.

In addition to their diversity in the questions about time stress and the data on time use, the data sets contain different measures of incomes or earnings. To make the results more comparable across all five data sets, we include the single measure, total household income (or total household earnings) in the equations describing time stress. (Since we restrict the analyses to households with at least one working partner, the differences between income and earnings are unlikely to be important.) By including this measure and hours of market work we are approximating as closely as possible full income, the theoretical construct in Section II. $^{6}$ The

\footnotetext{
${ }^{5}$ Questions similar to those in the QAL were asked of some of the respondents in the 1982 and 1996 U.S. General Social Surveys. Because these samples are smaller even than the QAL, and because the data may not be entirely comparable, we do not include them in the analysis.

${ }^{6}$ Time prices - hourly wage rates - are unavailable in any of the data sets; and creating them by dividing earnings by hours of market work generates the usual problems of division bias (Borjas, 1980).
} 
basic equations thus describe perceived time stress by hours of market and non-market work, and income, health status and a large number of control variables.

\section{A. Australia, 2001, Germany, 2002}

The distributions of responses on perceived time stress in the 2001 wave of the Australian HILDA and the 2002 German SOEP are shown in Table 1, first for partners in all couples with a working spouse, then for partners in two-earner couples. ${ }^{7}$ In all cases perceived time stress is greater among women than men. The differences by sex are slightly greater in two-earner couples, suggesting (since women are less likely to be the worker in one-worker households) that differences in the incidence of market work are an important determinant of differences in time stress. In these data most members of couples that are not entirely out of the labor force perceive substantial time pressure (perhaps a recognition of the time constraint that everyone faces). That pressure is somewhat greater when both partners are in the labor market.

Of particular interest is the relationship between the partners' stress. As the chi-squares show, these are not independent: Where one partner is more stressed for time, so is the other. This provides an empirical basis for the view in Section II that perceived time stress should be analyzed in the context of the family's time constraint. Whether these interactions are determined by similar underlying tastes, by objective unmeasurable variables, or by the impacts of one partner's observable activities on the other's time stress cannot be inferred from this simple test.

Given the wealth of information on time use in the HILDA and the SOEP, it is worth examining some of the crucial variables. Table 2 presents the means and standard deviations of these variables separately by gender for the two types of couples. (Where the definitions differ between the two countries, the categories in parentheses describe Germany.) In both countries one set of questions asks the respondent about his/her main job, both the weekly hours worked

\footnotetext{
${ }^{7}$ Throughout this Part we include both married couples and the substantial number of (typically younger) couples who state they are in permanent partnerships. This recognizes the nature of contemporary household relationships in Australia and Germany. Eleven (12) percent of the couples in the larger sample in Australia (Germany) are partnered rather than married, as are 13 (14) percent of the couples in the twoworker sample.
} 
and the number of days on which work is performed. ${ }^{8}$ Another series of questions asks how hours in a typical day are distributed across a set of seven categories of activities. We aggregate those that might be viewed as household work or as dependent (child and elder) care and concentrate on those aspects of non-market work. We multiply these responses by 7 to make them comparable to the data on weekly hours of market work.

Most of the statistics seem quite reasonable: Where both spouses work in the market, men's total hours on all jobs are longer, and they work more days per week. Among two-earner households Australian men's hours of dependent care and errands/housework are far below those of women, to the point that the total of these and market work hours is somewhat less (62 hours per week) than that of their partners (66 hours per week). Among two-earner German households the comparable figures are 58 and 69 hours. The excess of female over male total work hours is about the same among all couples in Australia as it is in two-earner couples, but it is even larger in the sample of German couples with at least one working partner. Unsurprisingly, given the relatively small dispersion of hours of market work in Germany (Hamermesh, 1996, Ch. 2), the deviation from a five-day workweek is much smaller in the German sample.

The HILDA provides information on each partner's income, and we use the sum of these throughout the analysis. For the SOEP we use twelve times the sum of the partners' gross monthly pay, computed as monthly pay plus $1 / 12$ of extra pay $\left(13^{\text {th }}\right.$ and $14^{\text {th }}$ month pay, Christmas pay and vacation bonus), in recognition of German wage-payment institutions. The resulting averages accord with published reports (Borland, 1999; Gerlach, 1987).

For Australia we define the person as stressed if he/she responds as being always or often stressed for time, thus including about half of the samples as being stressed. Aside from the central variables of interest, in this and the subsequent Parts we also adjust for a number of

\footnotetext{
${ }^{8}$ Data are also available on weekly hours of moonlighting. Only 6 percent of the men and 5 percent of the women in each country report such other work, with the mean weekly hours on second jobs equaling 12 for men and 10 for women (7 for both sexes in Germany) among those who moonlight. Since days worked on the second job are not reported, and since the fractions working such jobs and the hours worked on them are quite small, we ignore them in the analysis that we present. Replacing hours on the main job with hours worked on all jobs has, unsurprisingly, only minute effects on the estimates in Tables 3 and 4.
} 
demographic variables that might affect perceived time stress. In Australia these include indicators of urban residence, immigrant status and whether the couple is married. Also included here, but not presented in the tables, are indicators of the number of pre-school and school-age children. Finally, here and later we also include measures of the partner's hours of market work and hours spent on each of the aggregates of non-market work.

Table 3 presents estimates of the probit functions relating whether the respondent is always or often stressed for time to the major variables of interest. Each coefficient shows the impact on the probability of being stressed of a one-unit increase in the variable. The estimates are presented separately for men and women, and for all couples with a worker and for twoearner couples only. The sample sizes are substantially smaller than those implied by the statistics in Table 1, mainly because data on the broad measure of household incomes are missing in about 20 percent of the cases.

The central contribution of economic analysis to the discussion of time stress is its emphasis on the role of command over market goods in generating stress. The crucial prediction is that, other things equal, respondents in higher-income households will state that they are more stressed for time. Except for men in two-worker households, where we find no effect, the estimates corroborate this prediction: The effect of additional household income, holding all other characteristics constant, is positive, and it is statistically significant for Australian women.

Working the same number of hours per week spread over additional days, has a negative, but statistically insignificant effect on perceived stress. Additional housework has no effect on men's perceived time stress, but it does have a small and statistically significant effect on women's stress. Additional hours of dependent care each week surprisingly have no impact on women's time stress, but they do raise men's perception of time stress. It is worth noting (not shown here) that, holding constant weekly hours of dependent care, additional children have little effect on men's perceived stress. An additional pre-school child, however, generates a significant 
increase in a woman's probability of being stressed for time of 0.09 , while each school-age child increases this probability by 0.07 .

The theory in Section II implied that factors that generate greater efficiency in producing commodities at home are equivalent to increases in endowments of goods and time and lead, other things equal, to a reduction in time stress. The results in Table 3 corroborate this view: The roughly 60 percent of the sample that is in excellent or very good health is from 6 to 13 percentage points less likely to be stressed for time than otherwise comparable respondents. Moving from poor to very good or excellent health has the same effect on perceived time stress as a ten-hour reduction in weekly hours of market work.

To isolate the effects of differences in income and time use on perceived time stress in the German data, we again control for a set of demographic and related factors. These include indicators of residence in the former East Germany, location in a city of at least 100,000 people, presence of pre-school children, and a measure of the number of children. We capture potential differences between types of couples by an indicator of whether the partners are married and include measures of the partner's hours of market and homework. Finally, since pressures on self-employed workers may differ from those on employees, an indicator of self-employment status is also included.

As in the Australian data, we capture perceived time stress in Table 4 by estimating probits describing the impacts of these variables on the probability that the person responds that he or she is always or often stressed for time, thus defining between one-third and 40 percent of the partners as stressed. Table 4 lists the estimated derivatives of the probit functions and their standard errors for individuals in couples with at least one working partner, and for those in couples with two working partners. Additional household income generates significant increases in the time stress perceived by men and women, both in the sample of all working couples and among two-earner couples. 
Hours of work have significant and essentially identical positive effects on perceived time stress for both sexes. As in Australia, spreading work over additional days reduces time stress, but here some of the estimates are statistically significant. Among men additional time spent in dependent care and cleaning-cooking-shopping has little effect on time stress. (Remember from Table 2 that German men devote almost no time to these activities.) Among women, however, additional time in dependent care has a substantial and significant positive impact on time stress. While the impacts of additional time spent cleaning-cooking-shopping are not statistically significant, they are positive (and larger for women in two-earner households).

Being in at least good (self-reported) health has very large negative effects on the probability of being stressed for time. Moving from less than satisfactory to satisfactory selfassessed health has the same impact on perceived stress as at least a ten-hour decline in weekly work hours. Although the variable is not quite comparable to that defined for Australia, redefining it to make it as closely comparable as is possible does not alter the conclusion that selfreported good health is very strongly negatively related to perceived time stress.

\section{B. Korea, 1999, Canada, 1998}

The distributions of the four possible responses to the question, "How often do you feel rushed or pressed for time?" in the Korean Time Use Survey of 1999 are shown in Table 5. For Canada we combine responses indicating time stress once a week and once a month, and those indicating stress less than once a month or never, since those individual responses were uncommon. In the KTUS only those couples that filled out time diaries for two days are included in the samples used here, and only those for whom both days were weekdays. The paucity of respondents in the Canadian GSS and the existence of time diaries for only one day require us to use all respondents, including those who kept time diaries for weekend days.

Among couples with at least one worker perceived time stress is greater among men than among women in the Korean data. Even in this group for Canada we find the same result as in Table 1 for Australia and Germany_-greater time stress among women. The unusual finding in 
Korea probably stems from the lower female participation rate than in the West, so that a larger fraction of couples in the upper left part of Table 5 contains only male workers. When we examine responses of two-earner couples, shown in the bottom of Table 5, we find for both countries that time stress is far greater among working wives than among their working husbands, with the differences being even larger than those found in Australia and Germany. As in Australia and Germany, the responses of the Korean spouses are not independent: A husband/wife whose spouse says she/he is more stressed for time is more likely to respond that he/she is stressed for time.

The main reason for using the KTUS and the Canadian GSS is that, unlike the other data sets used here, they contain information from time diaries. This departure allows us to examine whether the measurement error inherent in the CPS-type recall data on work hours used in Part A of this Section might be biasing the estimated impacts of market and other work hours toward zero and thus overstating the relative importance of full-income differences in affecting time stress. To reduce measurement errors still further, in the Korean data we average the time-use variables over the two weekday diaries.

Table 6 presents the means and standard deviations of the time-diary measures of market work, household care and family care for Korea and Canada, along with statistics on CPS-type (recall) measures of weekly work hours. (Where the definitions differ between the countries, the Canadian definition is in parentheses.) For Korea the diary measures are daily hours, while for Canada, where diaries for all 7 days are used, we multiply daily hours by $7 .^{9}$ Korean men do remarkably little at home, much less even than their Australian or German counterparts. In twoworker households on a typical workday the wife spends close to two more hours than her husband in market work, household work and family care. In Canada the time diaries also

\footnotetext{
${ }^{9}$ Rather than use hours of work on the weekend, for the $2 / 7$ of the sample that is surveyed on the weekend we calculate their daily hours of market work as $1 / 5$ of their reported weekly hours.
} 
indicate that women do more work than men. The differences, roughly two hours per week, are remarkably similar to the respondents' recollections in the Australian data. ${ }^{10}$

For Korea the bottom rows of each half of Table 6 describe the family's imputed earnings, imputations that are necessitated by the absence of any earnings or income information in the KTUS. We took a 10-percent random sub-sample of the 1999 Korean Wage Structure Survey to estimate standard log-earnings regressions separately by sex for working married persons, including all the variables that might affect wages and that are common to both surveys. ${ }^{11}$ Using the parameter estimates, we imputed monthly earnings for each respondent in the KTUS, summed each spouse's imputed earnings and multiplied by 12 to obtain imputed annual earnings. The Canadian GSS does not provide earnings data but, like the Australian HILDA, we use information on each spouse's income.

For Korea the totals, roughly 18 and 24 million won (US\$15,000 and US\$20,000), accord well with information on household incomes. ${ }^{12}$ The small standard deviations, induced by our using imputations, underscore the point that the absence of income or earnings measures means that we are necessarily introducing errors into the income variables used to predict perceived time stress. Exactly opposite the case of the measures of time use, the income measures contain more measurement error than those in the previous Part, so that for Korea we will understate the

\footnotetext{
${ }^{10} \mathrm{~A}$ major reason for using these data sets was to compare the results of basing the estimates on time-diary reports of hours as opposed to the recall data that were available for Australia and Germany. We know that Koreans do not work in the market on Sundays, and Saturday workdays are typically not so long as weekday schedules. An upper bound for actual weekly work hours in Korea is thus six times average daily hours, roughly 50 for men and 42 for working women. These estimates are far below the CPS-type answers about weekly hours worked that are included in the data set and whose means are shown in the second rows of the left half of Table 6. For Canada the comparisons are direct, and there too the recall data indicate far longer hours of market work than the diary data. These shortfalls reproduce within data sets inferences drawn from comparisons of time-use and CPS surveys in the U.S. (see Juster and Stafford, 1991).

${ }^{11}$ The regressions are estimated over 13,353 married men and 2851 married women respectively. Each includes quadratics in monthly work hours and age, and vectors of indicators of educational attainment, occupation and industry. The adjusted $\mathrm{R}^{2}$ in the equation for men is 0.42 , in that for women, 0.53 . Annual bonuses, on which the data may be less reliable, are excluded from the earnings variable.

${ }^{12}$ The National Survey of Household Income and Expenditures shows that the average household with earners has 1.49 earners and has an average labor income of 22.48 million won.
} 
relative importance of income differences in determining time stress. The sample data on total incomes for husband-wife households in Canada in which the wife works in the market are close to the average family income of such households in the 1995 Census, $\$ 67,894$.

Table 7 shows the results of estimating probits describing the chance that a respondent in the KTUS states that he/she is always under time pressure (between 26 and 42 percent of the samples). The estimates are presented in exactly the same form as those in Tables 3 and 4 . In these equations we also include indicators of location and metropolitan residence, of the presence of pre-school children, a continuous measure of the number of household residents age 10 and over and measures of the spouse's time use. The essential results are remarkably similar qualitatively to those in the first Part of this section. Additional (diary) hours of market work have highly significant positive effects on perceived time stress. Household work also has significantly positive effects on time stress, but additional time spent in family care affects time stress significantly among women only if we include both one- and two-earner households.

Holding market and non-market work hours constant, individuals with higher (imputed) household earnings are more likely to respond that they are always stressed for time. These results replicate perfectly the findings for Australia and Germany-higher full income, like additional market and household work, leads to greater perceived time stress.

The coefficient estimates in Table 8 are from probits on the Canadian GSS data indicating whether the respondent states that he/she is always rushed (between 52 and 59 percent of the respondents). The samples are substantially smaller than those on which the statistics in Tables 5 and 6 are based, because the health measure and information on the spouse's hours are missing for many respondents. Despite the fairly small samples, however, the results on hours of market work look very much like those we have generated for the other countries, with highly significant positive effects on the probability of being stressed. Additional time spent on nonmarket work activities increases the probability that the respondents claim to be rushed, but the effects are much less on a per-hour basis than those of additional hours of market work. 
Holding hours of market and non-market work constant, for Canada too we find that additional income increases household members' feeling of being rushed. The effects are positive in all four samples, significantly so for men. As the discussion in Section II predicted, and as in Part A, those respondents whose self-assessed health is better (about 40 percent of the samples) are less likely to state that they are rushed, with the effects being substantial for men.

The data for these two countries allow us to examine whether using time-diary instead of recall data affects the results. For Korea we re-estimated the equations by replacing the timediary measures of market work with the CPS-type responses (since recall data on non-market work times were not available). As expected, the parameter estimates were not quite so significantly nonzero, and their implied impacts on time stress were slightly lower. The Canadian GSS contains recall data on all non-market work (similar to the HILDA and the SOEP), and we used recall measures for all three time-use variables. The estimates using these recall measures typically implied larger effects of market work hours on time stress, but the differences were not great. The estimated coefficients on the income/earnings measures were hardly affected in either country. Overall these additional results suggest that using CPS-type measures of hours instead of diary measures does not induce large biases in the parameter estimates.

\section{United States, 1971 and 1978}

The American QAL allowed only three possible responses to the question about time pressure. Moreover, having fewer respondents, these surveys are less likely to generate the kind of convincing results shown above and should thus be viewed as providing weaker tests of the theory, and somewhat less information on time stress. Nonetheless, because they are the only large-scale data sets available to analyze this issue for the U.S., it is worth using the information. Because the QAL samples are fairly small, we pool the data for 1971 and $1978 .^{13}$

\footnotetext{
${ }^{13}$ The 1978 QAL contained a longitudinal component that included some of the respondents in the 1971 QAL. We include each such respondent once here, using his/her data for 1978 only.
} 
The distributions of perceived time stress across the three possible responses are shown in Table 9. Even in the sample of people in couples with one or two working spouses, in most of which it was the wife who was not working, women are less likely than men to state that they are sometimes rushed or almost never rushed. When both spouses work in the labor market, a substantially higher fraction of the women indicated that they are always rushed for time, and a much smaller fraction indicated that they are almost never rushed. As in the other samples, women, especially wives who work in the labor market, are more stressed for time.

Unlike in the previous Parts, in Table 10 we present ordered probits describing the effects of hours of market work, health (no health problems) and annual household income on perceived time stress. We use ordered probits because the large majority of respondents are in the middle category (rushed sometimes) and because the number of possible categories is small. We include indicators for geography (location in the South and in an SMSA), for whether the person or one of his/her parents is an immigrant, for self-employment status and for the presence of a preschool child, and a continuous measure of the number of children in the household.

Despite the small samples and the lack of detailed data on spouses, the results are quite similar to those in the previous Parts. Additional hours of market work significantly shift respondents to categories indicating more time stress. As in the other samples additional household income generates additional perceived time stress. In both samples the positive effects are statistically significant at least at some low level of confidence. The health measure does not consistently produce the expected negative impact on perceived time stress (although the only statistically significant effect is negative).

\section{Additional Tests, Robustness Checks and Extensions}

We have restricted ourselves to specifications that allow the greatest commonality across the many data sets we have used in order to test the central and surprising prediction of the economic model — that, other things equal, people with higher full incomes will feel more time stress. A large variety of alternative specifications suggest themselves, and here we examine 
these on the data sets that allow the testing (in most cases the HILDA and the SOEP, the most extensive of the data sets we have used).

Perhaps the simplest and potentially most convincing check comes from a unique aspect of the German data: In addition to the regular sample, a special large sample of high-income households $\left(97^{\text {th }}\right.$ percentile or above) was drawn. Among married nonworking (in the market) women with working husbands in the high-income sample, 18.8 percent felt stressed always or often, while only 14.2 percent of the married nonworking women with working husbands in the random sample did. Obversely, only 39.4 percent of the rich nonworking wives felt never or almost never stressed, while 49.4 percent of average nonworking wives did. This stark comparison suggests the role of additional household income in increasing the Lagrangean multiplier in the household's time constraint.

While we have combined the earnings/income measures for spouses into household earnings/income, the model in Section II suggested that their effects might be expected to differ. We thus re-specify the probits for Australia and Germany to separate out the partners' earnings/incomes. In none of the eight probits can we reject the hypothesis that the effect of one's spouse's full income on one's perceived time stress is the same as the effect of one's own full income. Implicitly, at least in terms of the time stress that is generated by household production, an income-pooling model cannot be rejected.

Among the potential misspecifications of the estimating equations are several that would arise outside an economic model. Perhaps most important, what if time stress is not caused by the rush to spend higher incomes in the same amount of time, but is instead linked to occupation - that high-pressure occupations generate more time stress? For Australia and the United States we added vectors of one-digit occupational indicators to the estimating equations to examine this hypothesis. In neither country can we reject the hypothesis that this vector as a whole is zero, and including it reduces only slightly the impacts of the measures of household income/earnings on perceived time stress. This re-specification is an especially stringent test of 
the underlying hypothesis, as the occupational indicators are related to household income/earnings in both countries. ${ }^{14}$

Time stress may diminish even for the same hours of market work as individuals become more accustomed to their workplaces and their jobs. To examine this possibility (which does not stem from the model), we add measures of job tenure to the probits for two-earner households in Australia and Germany. Neither linear nor quadratic versions of this variable have any impact on perceived time stress, and their inclusion does not alter our inferences about the role of household income/earnings. A related argument, that perceived time stress is a biological outcome stemming from aging, is refuted: Using the same data sets, linear and quadratic forms in the respondent's age had no significant impacts on the probability of being stressed for time and did not qualitatively affect our inferences about the effects of full income.

While a measure of health-essentially proxying the efficiency of household production - is suggested by our model, those we have used have two unavoidable problems: 1) They are inherently subjective, meaning that we are relating a subjective measure (perceived time stress) to another subjective measure (self-reported health) ${ }^{15} ; 2$ ) They are based on current health, not long-term efficiency in the household. The former concern cannot be circumvented, but the positive correlation between good health and income suggests that any bias that it may induce in the estimated parameters of the crucial income/earnings variables is negative. In re-estimates of the basic model for all countries for which we had health measures this is exactly what we findexcluding measures of health increases the estimated impacts of income/earnings on time stress. Finally, if in the longitudinal SOEP we use last year's perceived health instead of its current value, again we find that the estimated effects of household earnings on time stress increase.

\footnotetext{
${ }^{14} \mathrm{We}$ also modified the model to include quadratics in own hours of market work. While the quadratic terms were sometimes significant statistically, their signs were not uniform across the equations, and the respecifications did not alter our conclusions about the role of household income/earnings.

${ }^{15}$ Some evidence (Butler et al, 1987) suggests that at least for workers objective measures are very highly correlated with self-reported health.
} 
Although it is difficult to construct a scenario by which simultaneity between time stress and full income might arise, it is worth trying, within the limits of the available data, to construct an instrument for current full income. The only sensible possibility is provided by the SOEP, whose 2001 wave contains each household's gross annual pay. We used Year 2001 earnings to re-estimate the probits over all couples that responded to the 2001 and 2002 surveys. Compared to the same equations estimated over these (reduced) samples, but with Year 2002 earnings, the equations described differences in time stress better: In all cases the coefficients on household pay in Year 2001 exceeded the corresponding coefficient in Table 4 (and also in untabled equations on these same reduced samples), and the coefficients were generally more significant statistically than those presented in Table 4. The estimates indicate that at least one possible, although seemingly not very plausible concern about simultaneity is not a problem in these data.

The estimates exclude one possibly stressful activity — commuting time - that may be correlated with earnings. To examine whether this exclusion affects our results, we re-specified the basic equations for Australia and Korea, for which data on hours spent commuting were available. For Australia commuting time had positive but insignificant effects on time stress and no qualitative impact on the estimated effects of household income. In Korea increased commuting time did raise time stress significantly, but there too it had no effects on our inferences about the role of additional earnings.

Except for the United States the estimates are presented for simple binary definitions of stress in order to aid in interpreting the results. We re-estimated the equations using ordered probits describing all possible responses to the questions on time stress in each survey. In nearly all cases the coefficients on household incomes in the ordered probits were more significant statistically than those in the simple probits. The estimates we present in Parts A and B thus understate the statistical significance of the effects of differences in household incomes/earnings.

In the estimation for Australia, Germany and Korea we have treated the equations describing partners' perceived time stress as independent, despite the evidence in Tables 1 and 5 
that they are not. Additional statistical efficiency can be gained if instead we view each partner's perceptions as jointly determined and estimate each of the pairs of equations in Tables 3,4 and 7 jointly as a bivariate probit. The re-estimates never generate changes in the parameter estimates of more than one in the second significant digit, nor do they alter the statistical significance of the parameter estimates. They do, however, allow us to examine the cross-partner correlations in the errors. The estimated correlation coefficients (and their t-statistics) are 0.211 (5.43) and 0.193 (4.07) in Australia, 0.307 (9.52) and 0.357 (8.89) in Germany, and 0.424 (13.16) and 0.513 (12.76) in Korea. They indicate the clear presence of unobservable characteristics that stress both partners simultaneously in all three countries.

One might argue that all we have shown is that adults in high-income families complain a lot-higher income may lead people to complain about everything or may be correlated with complaints in a variety of areas. If that is true, higher-income people will be more likely to complain about their incomes than other people, other things equal. Contrariwise, in the theory in Section II the Lagrangean multiplier $\mu$ on the income constraint becomes less binding as full incomes rise. Following the same argument that linked predictions about impacts on $\lambda$ to changes in incomes, we can link increases in incomes to effects on $\mu$ and infer that they will reduce people's income stress. People in households with high incomes will perceive more time stress but should be less likely to feel that their incomes are inadequate.

The Australian and German surveys ask respondents, "How satisfied are you with your financial situation [household income];" the Canadian GSS asks, "Please rate your feelings about your finances." We estimated ordered probits describing satisfaction with income, including the same regressors as in Tables 3,4 and 8. They make it clear that respondents with higher household incomes are more satisfied with their incomes than other people. Not surprisingly too, members of the higher-income households exhibit greater satisfaction with life, other things equal. A higher full income increases our proxy for the shadow value of time, reduces the proxy for the shadow value of goods, and increases a proxy for the level of the value function. 


\section{Crunch or Kvetch, and Whose?}

The results make it clear that additional hours of market work increase perceived time stress. They also demonstrate the fundamental economic point that, holding hours of market and household work constant, additional income also leads to greater time stress. People do perceive themselves as being in a time crunch, but they are kvetching because they have too much money given the time that they have chosen to leave over from market and household work to combine with their incomes. This kvetching does not mean that people could enhance their utility by giving up income: We assume that we are dealing with people who are maximizing utility but who are simply unhappy about the exogenous limits on their available time.

The more interesting question is the relative importance of the effects of limits on time and increases in income on perceived time stress. To examine this question in comparable ways across the data sets we use the results in Tables 3, 4, 7, 8 and 10 along with the order statistics of the underlying variables to estimate the impact of increases in market hours and incomes on the probability of stating one is stressed for time. Consider:

$$
\Delta_{\mathrm{YH}}=-\beta_{\mathrm{Y}} \Delta \mathrm{Y} / \beta_{\mathrm{H}} \Delta \mathrm{H},
$$

where the $\beta$ are the estimated probit coefficients (ordered probit in the case of the U.S.), and $\Delta Y$ and $\Delta \mathrm{H}$ are changes along the quantiles of the distributions of household income/earnings and hours. We present calculations for movements from the $25^{\text {th }}$ to the $75^{\text {th }}$ and the $10^{\text {th }}$ to the $90^{\text {th }}$ percentiles of the underlying variables. For all countries except Korea this is straightforward: We just use the distributions for the particular samples used in the estimation. Because we imputed earnings in Korea, we assume that the earnings distribution in this sample exhibits the same inequality as in the Korean National Survey of Household Income and Expenditures and use our sample means and the parameters of that distribution to simulate the impact of changes across earnings quantiles. ${ }^{16}$

\footnotetext{
${ }^{16}$ Quantile differences in earnings in Korea in the late 1980s look similar to those in Western Europe (Topel, 1999); and the survey data on which we base the simulations look very much like those in Topel.
} 
Table 11 presents estimates of $\Delta_{\mathrm{YH}}$ for each of the four samples in all five countries. They demonstrate that increases along the distribution of hours of market work generate greater increases in perceived time stress than do increases across the same percentiles of the distribution of household income/earnings. Nonetheless, increases in full income do substantially increase time stress. Because the definition of time stress differs among the five countries, as do the distributions of hours of work and income, comparisons across the data sets must be considered highly tentative. The greater relative importance of income differences in North America, and particularly in the United States, may, however, explain why the notion of time crunch is discussed more widely here.

Although the comparisons in Table 11 implicitly treat increases in hours of work and in full incomes as exogenous, the former surely are not. So long as labor supply curves are upward sloping, even these comparisons mean that we are understating the relative importance of increases in full incomes in generating complaints about being stressed for time. In the end we cannot really answer whether there is a time crunch or whether the complaints are yuppie kvetching. We can be sure, however, that at least some of the complaints result from differences across households in their members' full incomes.

As Tables 1, 5 and 9 showed, among two-earner couples the probability of stating one is time stressed is greater among wives. Taking the couples from the three countries whose data describe both partners, we can ask whether the sex difference arises from differences in the responses to each spouse's characteristics, or from differences in the characteristics themselves. We thus estimate a standard decomposition, asking how the predicted mean fraction stressed would differ if the males' outcome were determined the same way as the females' and vice-versa.

Table 12 presents this decomposition for each of the three countries, with the actual fraction stressed shown in italics on the prime diagonals. ${ }^{17}$ In both Australia and Germany if the

\footnotetext{
${ }^{17}$ The fractions are not exactly those listed in Tables 2 and 6 , because the probits are nonlinear and because for Australia the samples used in the probits differed very slightly from those for which the means are tabulated.
} 
wives had their partners' characteristics (same hours of market and non-market work, and same health) they would express still greater time stress (lower left in each part); if husbands had their wives' characteristics, they would express less time stress (upper right). At least in terms of this standard decomposition it appears that women in two-earner Western households are more likely to complain of being stressed for time at a given amount of market and non-market work than are their partners. This arises partly because in both countries the biggest measurable determinant of time stress is hours of market work, and men work more hours in the market; partly too in Australia it stems from a larger intercept in the probit for wives. The results differ in Korea: If husbands or wives switched roles, both would be more stressed.

This decomposition in the two Western economies suggests that working wives complain more about being rushed for time than would working husbands placed in an observably similar situation, but interpreting this result requires care. While we have included measures of time spent in childcare and of the number and ages of children, we know (Gronau and Hamermesh, 2001) that women do more different things during the day and may spend more time coordinating activities. It is also possible that wives maintain general responsibility for the household's operation independent of the number of children, their ages and the time spent caring for them and the household. This managerial effect may generate women's greater feelings of time stress. It is clear from the decomposition, however, that they are not caused by differences in measured characteristics.

\section{Conclusions}

We have proposed an economic theory that yields specific predictions about the impact of additional income on individuals' perceived time stress and have tested the model on a large variety of data sets covering five developed economies. The results are qualitatively remarkably consistent across countries: While additional market work does generate additional time stress, additional income, holding hours of market and homework fixed, also increases time stress. The 
relative sizes of these effects vary, but the impact of higher full incomes seems greater in North America than elsewhere.

The results suggest that at least some of the concern about a time crunch may be misplaced: Complaints about insufficient time come disproportionately from higher full-income families, partly because their members choose to work more hours, partly too because they have higher incomes to spend during each day. Whether one should be concerned about these complaints or simply view them as yuppie kvetching is a matter of values. In a world in which sympathy is scarce, however, it seems reasonable to argue that the time crunch-a more tightly binding time constraint — may have a smaller claim on public sympathy than poverty — a more tightly binding goods constraint.

The theoretical model and most of the empirical analyses have yielded some surprising results, and also some mysteries that clearly call for additional research that can profit from economic thinking. Particularly interesting among the latter is the stark gender difference in perceived time stress, one that cannot be explained at all by differences in observable characteristics. The analysis can also be extended to consider satisfaction with income in a more rigorous way than has been seen in the burgeoning economics and immense psychology literatures. More important, however, thinking about the predictions for subjective psychological outcomes that result from consumers' utility maximization is something that should be useful in a variety of areas that are widely discussed in the other social sciences, that concern many laypeople, and to which economists have paid very little attention. 


\section{REFERENCES}

Gary Becker, "A Theory of the Allocation of Time," Economic Journal, 75 (June 1965): 492-517. , The Economic Approach to Human Behavior. Chicago: University of Chicago Press, 1976.

George Borjas, "The Relationship Between Wages and Weekly Hours of Work: The role of Division Bias," Journal of Human Resources, 15 (Summer 1980): 409-23.

Jeff Borland, "The Equal Pay Case-Thirty Years On," Australian Economic Review, 32 (Sept. 1999): $265-72$.

J. S. Butler; Richard V. Burkhauser; Jean M. Mitchell; Theodore P. Pincus, "Measurement Error in Self-Reported Health Variables," Review of Economics and Statistics, 69 (Nov. 1987): 644-50.

Angus Campbell and Philip Converse, The Quality of American Life, 1978. Ann Arbor: Institute for Social Research, 1984.

Angus Campbell, Philip Converse and Willard Rodgers, The Quality of American Life. Ann Arbor: Institute for Social Research, 1975.

Edward Diener and Robert Biswas-Diener, "Will Money Increase Subjective Well-Being?" Social Indicators Research, 57 (2002): 119-69.

Rafael Di Tella, Robert MacCulloch and Andrew Oswald, "Preferences Over Inflation and Unemployment: Evidence from Surveys of Happiness," American Economic Review, 81 (March 2001): 335-41.

Bruno Frey and Alois Stutzer, Happiness and Economics. Princeton, NJ: Princeton University Press, 2002.

Knut Gerlach, “A Note on Male-Female Wage Differences in West Germany,” Journal of Human Resources, 22 (Fall 1987): 584-92.

Reuben Gronau, and Daniel Hamermesh, "The Demand for Variety -- A Household Production Perspective," National Bureau of Economic Research, Working Paper No. 8509, Sept. 2001.

Michael Grossman, "On the Concept of Health Capital and the Demand for Health," Journal of Political Economy, 80 (March/April 1972): 223-55.

Daniel Hamermesh, Workdays, Workhours and Work Schedules. Kalamazoo, MI: The W. E. Upjohn Foundation, 1996.

Arlie Russell Hochschild, The Time Bind: When Work Becomes Home and Home Becomes Work. New York: Metropolitan Books, 1997.

Erlend Holz, "Time Stress and Time Crunch in the Daily Life of Women, Men and Families," Unpublished paper, Statistisches Bundesamt, Wiesbaden, 2002. 
F. Thomas Juster and Frank Stafford, "The Allocation of Time: Empirical Findings, Behavioral Models, and Problems of Measurement," Journal of Economic Literature, 29 (1991): 471-522.

Staffan Burenstam Linder, The Harried Leisure Class. New York: Columbia University Press, 1970.

Clarence Lochhead, "Factors Associated with Time Stess Among Mothers and Fathers in TwoParent Families," Unpublished paper, Canadian Labour and Business Centre, Ottawa, 2002.

Shelly Lundberg and Robert Pollak, "Bargaining and Distribution in Marriage," Journal of Economic Perspectives, 10 (Fall 1996): 139-58.

Juliet Schor, The Overworked American. New York: Basic Books, 1991.

Robert Topel, "Labor Markets and Economic Growth," in. Orley Ashenfelter and David Card, Handbook of Labor Economics, Vol. 3C. Amsterdam: Elsevier, 1999.

Gert Wagner, Richard Burkhauser and Frederike Behringer, "The Syracuse University English Language Public Use File of the German Socio-Economic Panel," Journal of Human Resources, 28 (Spring 1993): 429-33.

Bruce Weinberg, "An Incentive Model of the Effect of Parental Income on Children," Journal of Political Economy, 109 (April 2001): 266-80.

Mark Wooden, Simon Freidin and Nicole Watson, "The Household, Income and Labour Dynamics in Australia (HILDA) Survey: Wave 1," Australian Economic Review, 35 (2002): 339-48. 
Table 1. Percent Distributions of Time Pressure, Married/Partnered Individuals in Couples, Australia, 2001 (Germany 2002)

\begin{tabular}{|c|c|c|c|c|}
\hline & & LIA & GE & NY \\
\hline & MEN & WOMEN & MEN & WOMEN \\
\hline & & R TWO WC & ARTNE & \\
\hline $\begin{array}{l}\text { Under time pressure: }{ }^{\circledR} \\
\text { Almost Always } \\
\text { (Always) }\end{array}$ & 10.67 & 14.72 & 5.62 & 5.40 \\
\hline Often & 32.76 & 35.77 & 28.67 & 30.98 \\
\hline Sometimes & 41.89 & 39.27 & 38.20 & 41.74 \\
\hline $\begin{array}{l}\text { Rarely } \\
\text { (Almost Never) }\end{array}$ & 13.07 & 9.15 & 17.07 & 13.88 \\
\hline Never & 1.61 & 1.09 & 10.44 & 8.00 \\
\hline $\mathrm{N}=$ & & & & \\
\hline $\begin{array}{l}\text { Chi-squared of Indepe } \\
\text { of Partners' Distribut }\end{array}$ & $\begin{array}{l}\text { dence } \\
\text { ons } 1\end{array}$ & .001 & 417 & $\mathrm{p}<.001$ \\
\hline
\end{tabular}

TWO WORKING PARTNERS

\begin{tabular}{|c|c|c|c|c|}
\hline $\begin{array}{l}\text { Almost Always } \\
\text { (Always) }\end{array}$ & 10.70 & 16.10 & 6.41 & 6.41 \\
\hline Often & 34.23 & 38.98 & 31.44 & 35.98 \\
\hline Sometimes & 41.48 & 37.07 & 40.91 & 42.64 \\
\hline $\begin{array}{l}\text { Rarely } \\
\text { (Almost Never) }\end{array}$ & 12.27 & 7.39 & 14.05 & 9.87 \\
\hline Never & 1.32 & 0.45 & 7.19 & 5.18 \\
\hline $\mathrm{N}=$ & \multicolumn{2}{|c|}{1943} & \multicolumn{2}{|c|}{1796} \\
\hline \multicolumn{5}{|c|}{$\begin{array}{l}\text { Chi-squared of Independence } \\
\text { of Partners' Distributions } \quad 132.55, \mathrm{p}<.001\end{array}$} \\
\hline
\end{tabular}


Table 2. Means and Standard Deviations of Crucial Variables, Married/Partnered Individuals in Couples, Australia 2001 (Germany 2002)

AUSTRALIA

MEN

WOMEN

GERMANY

MEN WOMEN

ONE OR TWO WORKING PARTNERS

\begin{tabular}{|c|c|c|c|c|}
\hline $\begin{array}{l}\text { Weekly Work } \\
\text { Hours }\end{array}$ & $\begin{array}{l}43.64 \\
(17.58)\end{array}$ & $\begin{array}{c}22.97 \\
(19.13)\end{array}$ & $\begin{array}{l}39.38 \\
(17.59)\end{array}$ & $\begin{array}{c}21.67 \\
(18.19)\end{array}$ \\
\hline Days Worked & $\begin{array}{r}4.84 \\
(1.69)\end{array}$ & $\begin{array}{l}3.14 \\
(2.30)\end{array}$ & $\begin{array}{c}4.52 \\
(1.72)\end{array}$ & $\begin{array}{l}3.37 \\
(2.34)\end{array}$ \\
\hline $\begin{array}{l}\text { Weekly Errands, } \\
\text { Housework Hours } \\
\text { (Shopping, Eating } \\
\text { Cleaning Hours) }\end{array}$ & $\begin{array}{l}8.93 \\
(8.40)\end{array}$ & $\begin{array}{l}25.10 \\
(16.72)\end{array}$ & $\begin{array}{l}9.80 \\
(9.31)\end{array}$ & $\begin{array}{l}28.70 \\
(14.42)\end{array}$ \\
\hline $\begin{array}{l}\text { Weekly Dependent } \\
\text { Care Hours }\end{array}$ & $\begin{array}{c}7.23 \\
(10.71)\end{array}$ & $\begin{array}{c}14.97 \\
(21.83)\end{array}$ & $\begin{array}{l}4.62 \\
(8.96)\end{array}$ & $\begin{array}{l}19.11 \\
(32.76)\end{array}$ \\
\hline $\begin{array}{l}\text { Gross Annual Pay } \\
(A \$ 1000) \quad(€ 1000)\end{array}$ & $\begin{array}{l}41.017 \\
(35.463)\end{array}$ & $\begin{array}{l}19.287 \\
(21.065)\end{array}$ & $\begin{array}{c}33.01 \\
(36.58)\end{array}$ & $\begin{array}{l}13.26 \\
(22.84)\end{array}$ \\
\hline $\begin{array}{l}\text { Household Income } \\
(\mathrm{A} \$ 1000)(€ 1000)\end{array}$ & \multicolumn{2}{|c|}{$\begin{array}{l}74.269 \\
(48.852)\end{array}$} & \multicolumn{2}{|c|}{$\begin{array}{c}46.11 \\
(43.26)\end{array}$} \\
\hline
\end{tabular}

\section{TWO WORKING PARTNERS}

\begin{tabular}{|c|c|c|c|c|}
\hline $\begin{array}{l}\text { Weekly Work } \\
\text { Hours }\end{array}$ & $\begin{array}{l}46.99 \\
(14.04)\end{array}$ & $\begin{array}{c}31.61 \\
(15.33)\end{array}$ & $\begin{array}{c}44.81 \\
(10.46)\end{array}$ & $\begin{array}{l}30.83 \\
(13.66)\end{array}$ \\
\hline Days Worked & $\begin{array}{c}5.21 \\
(1.18)\end{array}$ & $\begin{array}{l}4.33 \\
(1.49)\end{array}$ & $\begin{array}{l}5.12 \\
(0.50)\end{array}$ & $\begin{array}{l}4.78 \\
(0.97)\end{array}$ \\
\hline $\begin{array}{l}\text { Weekly Errands, } \\
\text { Housework Hours } \\
\text { (Shopping, Eating } \\
\text { Cleaning Hours) }\end{array}$ & $\begin{array}{l}8.66 \\
(7.45)\end{array}$ & $\begin{array}{l}22.35 \\
(14.73)\end{array}$ & $\begin{array}{l}9.17 \\
(7.63)\end{array}$ & $\begin{array}{l}24.78 \\
(11.90)\end{array}$ \\
\hline $\begin{array}{l}\text { Weekly Dependent } \\
\text { Care Hours }\end{array}$ & $\begin{array}{c}6.54 \\
(9.95)\end{array}$ & $\begin{array}{c}12.26 \\
(18.54)\end{array}$ & $\begin{array}{l}4.41 \\
(9.26)\end{array}$ & $\begin{array}{l}13.80 \\
(25.82)\end{array}$ \\
\hline $\begin{array}{l}\text { Gross Annual Pay } \\
(\mathrm{A} \$ 1000)(€ 1000)\end{array}$ & $\begin{array}{c}42.504 \\
(33.539)\end{array}$ & $\begin{array}{c}26.862 \\
(20.563)\end{array}$ & $\begin{array}{l}36.73 \\
(38.51)\end{array}$ & $\begin{array}{l}18.98 \\
(27.05)\end{array}$ \\
\hline $\begin{array}{l}\text { Household Income (F } \\
(\mathrm{A} \$ 1000)(€ 1000)\end{array}$ & & & \multicolumn{2}{|c|}{$\begin{array}{c}55.47 \\
(47.52)\end{array}$} \\
\hline
\end{tabular}


Table 3. Probit Estimates of the Determinants of Time Stress, Australian Couples, 2001, (Dependent variable is whether stressed almost always or often) ${ }^{\mathrm{a}}$

ONE OR TWO WORKERS

\begin{tabular}{|c|c|c|c|c|}
\hline \multirow{2}{*}{\multicolumn{5}{|c|}{ Variable: }} \\
\hline & & & & \\
\hline $\begin{array}{l}\text { Weekly Work } \\
\text { Hours }\end{array}$ & $\begin{array}{l}.00824 \\
(.00111)\end{array}$ & $\begin{array}{l}.00773 \\
(.00133)\end{array}$ & $\begin{array}{l}.00833 \\
(.00138)\end{array}$ & $\begin{array}{l}.00801 \\
(.00142)\end{array}$ \\
\hline Days Worked & $\begin{array}{l}-.00591 \\
(.01112)\end{array}$ & $\begin{array}{l}-.0152 \\
(.0111)\end{array}$ & $\begin{array}{l}-.00544 \\
(.01544)\end{array}$ & $\begin{array}{l}-.0138 \\
(.0137)\end{array}$ \\
\hline $\begin{array}{l}\text { Weekly Errands, } \\
\text { Housework Hours }\end{array}$ & $\begin{array}{l}.00009 \\
(.00148)\end{array}$ & $\begin{array}{l}.00177 \\
(.00083)\end{array}$ & $\begin{array}{l}-.00037 \\
(.00196)\end{array}$ & $\begin{array}{l}.00185 \\
(.00116)\end{array}$ \\
\hline $\begin{array}{l}\text { Weekly Dependent } \\
\text { Care Hours }\end{array}$ & $\begin{array}{l}.00525 \\
(.00136)\end{array}$ & $\begin{array}{l}.00091 \\
(.00069)\end{array}$ & $\begin{array}{l}.00550 \\
(.00189)\end{array}$ & $\begin{array}{l}.00013 \\
(.00105)\end{array}$ \\
\hline $\begin{array}{l}\text { Excellent or Very } \\
\text { Good Health }\end{array}$ & $\begin{array}{l}-.0893 \\
(.0248)\end{array}$ & $\begin{array}{l}-.0968 \\
(.0261)\end{array}$ & $\begin{array}{l}-.0578 \\
(.0305)\end{array}$ & $\begin{array}{l}-.1287 \\
(.0313)\end{array}$ \\
\hline $\begin{array}{l}\text { Gross Annual House- } \\
\text { hold Income (A } \$ 1000)\end{array}$ & $\begin{array}{c}.00034 \\
(.00026)\end{array}$ & $\begin{array}{l}.00052 \\
(.00026)\end{array}$ & $\begin{array}{l}-.00004 \\
(.00033)\end{array}$ & $\begin{array}{l}.00078 \\
(.00034)\end{array}$ \\
\hline Pseudo $\mathrm{R}^{2}$ & .0709 & .0827 & .0589 & .0789 \\
\hline $\mathrm{N}=$ & & & & \\
\hline
\end{tabular}

TWO WORKERS

\begin{abstract}
(Dependent variable is whether stressed almost alwa
\end{abstract}
${ }^{a}$ Here and in Tables 4, 7 and 8 the coefficients are the effects of a one-unit increase in X on the probability of being pressed for time. Standard errors are in parentheses. The equations also include indicators of immigrant status, residence in one of the five major cities, married versus partnered, number of children under age 6, and number of school-age children. Also included are measures of the spouse/partner's health status, weekly hours and days of market work, dependent care and errands/housework. 
Table 4. Probit Estimates of the Determinants of Time Stress, German Couples, 2002, (Dependent variable is whether stressed always or often) ${ }^{\mathrm{a}}$

ONE OR TWO WORKERS

Variable:

Weekly Work

Hours

Days Worked
MEN

WOMEN

.0107

$(.0011)$

.0090

(.0010)
$-.0088$
(.0074)

.00091

(.00075)

.00157

(.00035)

$-.1459$

(.0287)

Health

$(.0304)$

.00064

(.00023)

.0790

Pseudo $\mathrm{R}^{2}$

$\mathrm{N}$

3006
.00058

(.00021)

.0797

\section{TWO WORKERS}

\section{MEN}

.0106

(.0014)

$-.0278$

(.0279)

$-.00175$

(.00166)

$-.00046$

(.00156)

$-.1247$

(.0416)

$-.1272$

(.0414)

.00053

(.00027)

.00057

(.00025)

.0512

.0620

.0099

$(.0013)$

$(.0150)$

.00183

$(.00115)$

.00176

$(.00063)$
1754

${ }^{a}$ The equations also include indicators of residence in the former East Germany, location in a city with population above 100,000 , whether a worker is self-employed, married versus partnered, whether the youngest child is under 6 , and a continuous measure of the number of children. Also included are measures of the spouse/partner's health status, weekly hours and days of market work, dependent care and errands/housework. 
Table 5. Percent Distributions of Time Pressure, Married Individuals in Couples, Korea, 1999 (Canada, 1998)

\begin{tabular}{|c|c|c|c|c|}
\hline & & & & DA \\
\hline & MEN & WOMEN & MEN & WOMEN \\
\hline Under time pressure (ru & Ished $)^{\mathrm{a}}$ & ONE OR T & KERS & \\
\hline Always & 28.18 & 26.34 & 51.86 & 54.05 \\
\hline $\begin{array}{l}\text { Often (A Few Times } \\
\text { a Week) }\end{array}$ & 42.58 & 42.18 & 25.14 & 26.43 \\
\hline $\begin{array}{l}\text { Rarely (About Once a } \\
\text { Week or a Month) }\end{array}$ & 20.58 & 22.82 & 15.77 & 13.52 \\
\hline $\begin{array}{l}\text { Never (Never or Less } \\
\text { Than Once a Month) }\end{array}$ & 8.67 & 8.65 & 8.22 & 6.00 \\
\hline $\mathrm{N}=$ & & & 2092 & 2285 \\
\hline
\end{tabular}

TWO WORKERS

$\begin{array}{lcccc}\text { Always } & 33.37 & 41.68 & 53.99 & 59.06 \\ \begin{array}{l}\text { Often (A Few Times } \\ \text { A Week) }\end{array} & 44.63 & 42.68 & 26.24 & 24.81 \\ \begin{array}{l}\text { Rarely (About Once a } \\ \text { Week or a Month) }\end{array} & 17.16 & 12.31 & 13.88 & 12.26 \\ \begin{array}{l}\text { Never (Never or Less } \\ \text { Than Once a Month) }\end{array} & 4.85 & 3.33 & & \\ \mathrm{~N}= & 2,104 & & 5.89 & 3.88 \\ & & & 1189 & 1314\end{array}$

Chi-squared of Independence

of Spouses' Distributions 458.19, $\mathrm{p}<.001$

aThe question (in translation) in Korea is: "How often do you feel rushed or pressed for time?" The responses are: "Always, often, rarely, never." The question in Canada is: "How often do you feel rushed?" The responses are: "Every day; a few times a week; about once a week; about once a month; less than once a month; never." 
Table 6. Means and Standard Deviations of Crucial Variables, Married Individuals in Couples, Korea, 1999 (Canada, 1998)

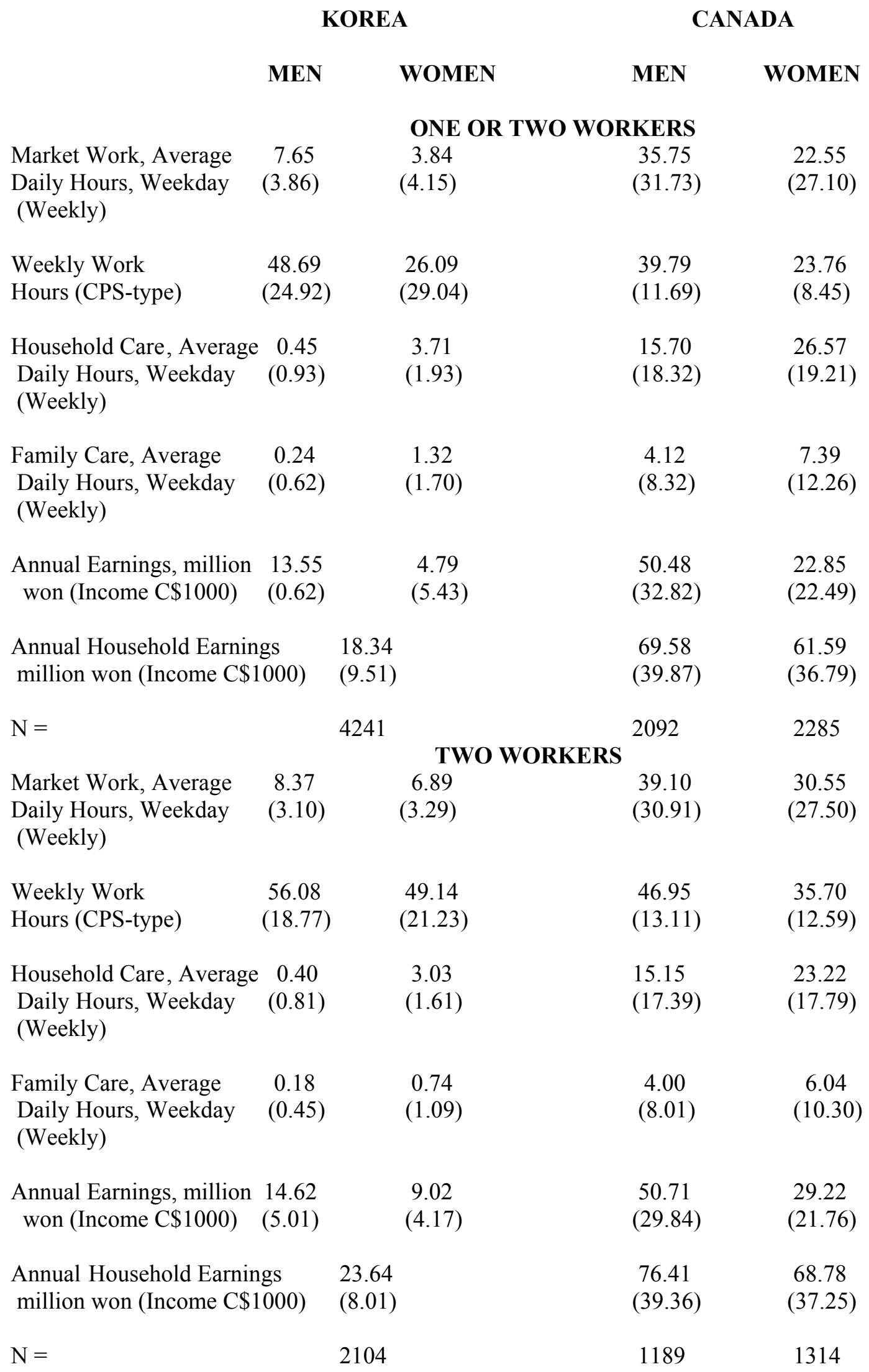


Table 7. Probit Estimates of the Determinants of Time Stress, Korean Couples, 1999(Dependent variable is whether stressed always) ${ }^{a}$

ONE OR TWO WORKERS

MEN

Variable:

Average Weekday

Work Hours

Average Weekday

Household Care

Average Weekday

Family Care

Gross Annual

Household Earnings,

million won

Pseudo $\mathrm{R}^{2}$

.1021

WOMEN

.0364

$(.0024)$

.0471

(.0024)

.0181

(.0046)

.0316

(.0057)

.00660

(.00090)

$(.00091)$

$\mathrm{N}=$

4241
TWO WORKERS

MEN

.0368

(.0042)

.0544

$(.0050)$

.0342

(.0091)

(.0141)

$-.0003$

(.0256)

.0168

(.0141)

.00271

(.00142)

.00793

(.00154)

.1805

.0531

.0788

2104

${ }^{a}$ Gross annual household income is calculated as 12 times monthly income imputed from a $10 \%$ sample of the Korea Wage Structure Survey 1999. The equations also include the number of household members age 10 or over, and indicators for the presence of pre-school age children, residence in Seoul, and residence in metropolitan cities except Seoul. Also included are measures of the spouse's weekly hours of market work, family care and household care. 
Table 8. Probit Estimates of the Determinants of Time Stress, Canadian Couples, 1998 (Dependent variable is whether rushed always) ${ }^{\mathrm{a}}$

ONE OR TWO WORKERS

\begin{tabular}{|c|c|c|c|c|}
\hline & MEN & WOMEN & MEN & WOMEN \\
\hline $\begin{array}{l}\text { Variable: } \\
\text { Average Weekday } \\
\text { Work Hours }\end{array}$ & $\begin{array}{l}.0320 \\
(.0042)\end{array}$ & $\begin{array}{l}.0269 \\
(.0051)\end{array}$ & $\begin{array}{l}.0287 \\
(.0065)\end{array}$ & $\begin{array}{l}.0235 \\
(.0070)\end{array}$ \\
\hline $\begin{array}{l}\text { Average Daily } \\
\text { Household Care }\end{array}$ & $\begin{array}{l}.0161 \\
(.0066)\end{array}$ & $\begin{array}{l}.0021 \\
(.0068)\end{array}$ & $\begin{array}{l}.0193 \\
(.0100)\end{array}$ & $\begin{array}{l}.0009 \\
(.0094)\end{array}$ \\
\hline $\begin{array}{l}\text { Average Daily } \\
\text { Family Care }\end{array}$ & $\begin{array}{l}.0216 \\
(.0153)\end{array}$ & $\begin{array}{l}.0242 \\
(.0118)\end{array}$ & $\begin{array}{l}.0188 \\
(.0222)\end{array}$ & $\begin{array}{l}.0159 \\
(.0182)\end{array}$ \\
\hline $\begin{array}{l}\text { Very Satisfied } \\
\text { with Health }\end{array}$ & $\begin{array}{l}-.0945 \\
(.0294)\end{array}$ & $\begin{array}{c}-.0327 \\
(.0304)\end{array}$ & $\begin{array}{l}-.1697 \\
(.0406)\end{array}$ & $\begin{array}{c}-.0355 \\
(.0384)\end{array}$ \\
\hline $\begin{array}{l}\text { Gross Annual } \\
\text { Household Income } \\
(\mathrm{C} \$ 000)\end{array}$ & $\begin{array}{l}.00081 \\
(.00038)\end{array}$ & $\begin{array}{l}.00053 \\
(.00046)\end{array}$ & $\begin{array}{l}.00107 \\
(.00054)\end{array}$ & $\begin{array}{l}.00070 \\
(.00054)\end{array}$ \\
\hline Pseudo $\mathrm{R}^{2}$ & .0690 & .0442 & .0737 & .0593 \\
\hline $\mathrm{N}=$ & 1268 & 1176 & 654 & 748 \\
\hline
\end{tabular}

${ }^{a}$ Also included in the equations are a measure of the spouse/partner's hours of market work, and indicators of marital status and the presence of pre-school, and school-age children, of major region, of metropolitan location, and of whether the diary is on a weekday. 
Table 9. Percent Distributions of Time Pressure, Married Individuals, United States, 1971 and 1978

$\begin{array}{cc}\text { MEN WOMEN } & \text { MEN WOMEN } \\ \text { ONE OR TWO WORKERS } & \text { TWO WORKERS }\end{array}$

Rushed $^{\mathrm{a}}$

$\begin{array}{lcccc}\text { Always } & 23.15 & 23.20 & 23.70 & 28.12 \\ \text { Sometimes } & 58.15 & 61.29 & 59.04 & 62.40 \\ \text { Almost Never } & 18.70 & 15.52 & 17.26 & 9.48 \\ \mathrm{~N}= & 1123 & 1276 & 481 & 601\end{array}$

${ }^{a}$ The question is: "In general, how do you feel about your time-would you say you always feel rushed even to do the things you have to do, only sometimes feel rushed, or almost never feel rushed?" 
Table 10. Ordered Probit Estimates of the Determinants of Time Stress, Married Americans with at Least One Working Spouse, 1971 and 1978

ONE OR TWO WORKERS

$\begin{array}{lllll} & \text { MEN } & \text { WOMEN } & \text { MEN } & \text { WOMEN } \\ \text { Variable: } & & & & \\ \text { Weekly Work } & .0131 & .0138 & .0187 & .0118 \\ \quad \text { Hours } & .0025) & (.0019) & (.0051) & (.0043) \\ \text { No Health Problems } & -.0167 & -.1407 & .0053 & -.3018 \\ & (.0845) & (.0816) & (.1319) & (.1248) \\ \text { Gross Annual } & .0040 & .0082 & .0039 & .0047 \\ \quad \text { Income }(\$ 1000) & (.0024) & (.0026) & (.0042) & (.0039) \\ \text { Pseudo } \mathrm{R}^{2} & .0262 & .0398 & .0195 & .0318 \\ \mathrm{~N}= & 1073 & 1145 & 456 & 547\end{array}$

${ }^{a}$ The coefficients are the estimated effects of one-unit increases in the $\mathrm{X}$ variables on the ordered probit index. Standard errors are in parentheses. The equations also include indicators of whether the spouse works, the presence of children under age 6, residence in the South, location in an SMSA, health status, whether a worker is self-employed, of immigrant or first-generation American, and for 1978, as well as a continuous measure of the number of children. 
Table 11. Ratio of Decreased Household Earnings/Income Needed to Offset Interquantile Increases in Work Hours to Hold Constant Perceived Time Stress, 5 Countries

\section{AUSTRALIA GERMANY KOREA CANADA UNITED STATES ONE- OR TWO-WORKER HOUSEHOLDS}

\section{Males}

$25^{\text {th }} \rightarrow 75^{\text {th }}$

$10^{\text {th }} \rightarrow 90^{\text {th }}$

Females

$25^{\text {th }} \rightarrow 75^{\text {th }}$

$10^{\text {th }} \rightarrow 90^{\text {th }}$

Males

$25^{\text {th }} \rightarrow 75^{\text {th }}$

$10^{\text {th }} \rightarrow 90^{\text {th }}$

Females

$25^{\text {th }} \rightarrow 75^{\text {th }}$

$10^{\text {th }} \rightarrow 90^{\text {th }}$
0.138

0.091

0.083

0.139

0.189

0.079

0.275

0.268

0.151

0.274

0.706

0.280

0.058

0.119

0.199

0.321

0.088

0.142

0.344

0.410

\section{TWO-WORKER HOUSEHOLDS}

$-0.013$

0.163

0.162

0.560

0.168

0.382

0.238

0.158

0.093

0.277

0.188

0.119

0.304

0.359

0.381

0.226

0.376 
Table 12. Decomposition of the Gender Difference in Time Stress, Two-Earner Couples, Australia, 2001, Germany, 2002, Korea, 1998 ${ }^{\mathrm{a}}$

\section{Predicted Fraction Stressed}

Coefficients $\quad$ Male $r$ Feans

AUSTRALIA

$\begin{array}{lll}\text { Male } & 0.447 & 0.387 \\ \text { Female } & 0.675 & 0.560\end{array}$

GERMANY

$\begin{array}{lll}\text { Male } & 0.371 & 0.230 \\ \text { Female } & 0.528 & 0.420\end{array}$

KOREA

$\begin{array}{lll}\text { Male } & 0.324 & 0.368 \\ \text { Female } & 0.422 & 0.408\end{array}$

${ }^{\mathrm{a}}$ The actual means are italicized. 